\title{
An experimental study on small scale sea water desalination unit through solar power in Cox's Bazar, Bangladesh
}

\author{
M. M. Islam*, S. A. Uddin, Z. Islam and M. I. Hossain ${ }^{1}$ \\ Institute of Marine Sciences and Fisheries, University of Chittagong, Chittagong-4331 Bangladesh, ${ }^{1}$ Department of \\ Fisheries, University of Rajshahi, Rajshahi-6205, Bangladesh, *E-mail: mohid9@gmail.com
}

\begin{abstract}
An experimental small scale desalination system where solar energy as the main heat source was conducted in a remote area of Cox's Bazar district of Bangladesh. In this investigation, the performance of three solar stills with transparent glass cover was studied. Treated sea water was given to the solar still and the quantity of distilled water from three solar stills was measured per day and the effectiveness of the stills was compared. The performance of

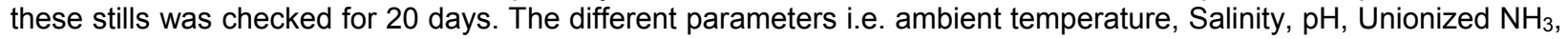
Iron, $\mathrm{NO}_{2}-\mathrm{N}$, Chlorine, $\mathrm{DO}$ and amount of distilled water were studied and analyzed. The average amount of water produced by the still (1) was $455 \mathrm{ml}$, still (2) was $394.75 \mathrm{ml}$ and still (3) was $339.25 \mathrm{ml}$. The total amount of water produced by the still (1) was $9100 \mathrm{ml}$, still (2) was $7895 \mathrm{ml}$ and still (3) was $6785 \mathrm{ml}$. The average desalinated water were obtained $1.06 \mathrm{liter} / \mathrm{m}^{2} /$ day, $0.98 \mathrm{liter} / \mathrm{m}^{2} /$ day and $0.95 \mathrm{liter} / \mathrm{m}^{2} /$ day from still 1,2 and 3 respectively.
\end{abstract}

Keywords: Water desalination, Drinking water, Solar power, Solar still, Bangladesh

\section{Introduction}

Water is one of the most fundamental components to life. Unfortunately, only $1 \%$ of the Earth's water is fresh water, the rest $99 \%$ is saline or contaminated, making it undrinkable (Bendfeld et al, 1998). This little amount of fresh water is inadequate to our living needs. Especially in densely populated and low rainfall areas, the shortage of water presents a considerable problem for our world.

At present more than 7,500 desalination plants are operated worldwide, $60 \%$ of which are located in the Middle East (Chaudhry, 2003). The world's largest plant in Saudi Arabia produces 128 MGD (Million gallons per day) of desalted water (California Desalination Task Force 2003). In contrast, 12\% of the world's capacity is produced in the Americas, with most of the plants located in the Caribbean and Florida.

Desalination of water can be done in many ways but we have to consider the cost of the unit production. Desalination by means of solar energy may be a suitable solution for providing fresh water to remote areas of Bangladesh. This solution becomes more competitive, especially for remote and rural areas where small quantities of water for human consumption are needed. For some time, a single-effect basintype solar still has been the cheapest way to produce drinkable water using solar resources. Daily production is small due to the rejection of the latent heat condensation, less than $4-5 \mathrm{~L} / \mathrm{m} 2$, with specific energy consumption around $7000 \mathrm{~kJ} / \mathrm{kg}$. Solar distillation has been reported in great detail, and many installations have been constructed based on the single-effect basin-type solar still (Howe and Tleimat, 1977 and Malik et al., 1982). At the Renewable Energies Department of INETI (Portugal), special attention was paid to small desalination units of multi-effect solar stills (Joyce et al., 1993) and evaporation type solar stills (Joyce et al., 1994) respectively with consumption of about 1800 and 800 $\mathrm{kJ} / \mathrm{kg}$.

Presently, Bangladesh is suffering for crisis of pure drinking water. In summer most of the major cities like Dhaka, Chittagong, Rajshahi suffer from water crisis. Rivers flowing near the major cities have become polluted and these water are becoming unsuitable for drinking after treatment in traditional plants. Excessive dependence on subsurface water has caused drastic lowering of water level making the country vulnerable to massive earthquake.

However, arsenic and saline contamination of groundwater is not a new problem in coastal area of the country although it has achieved unprecedented dimensions since the mid-80s due to sea level rise and unchecked shrimp cultivation. The resulting crisis, which now affects 12 million peoples of South western and South eastern part of Bangladesh. 
Moreover, in the past few years, shrimp culture is one of the largest single factor contributing to the increase of salinity in groundwater in coastal areas. The effects of increased salinity are far reaching and potentially devastating, not only for the natural landscape but also for those inhabiting it. Tube-wells that previously lifted sweet water are now lifting saline water from the ground in coastal areas. Excessive use of groundwater for irrigation in Boro paddy fields during the dry season are also results in damaging to underground water bodies. Because water is being lifted without being replenished, the groundwater level is going down. Women and children are the worst victims of the current salinity crisis in rural areas, as they have to fetch drinking water by walking over one to one and half kilometres through narrow katcha roads in some cases. Their suffering is most acute during the rainy season, when roads become slippery. A desalination plant removes dissolved salts and impurities from sea water to make it fit for drinking. Desalination plants can provide quality drinking water even when it does not rain. It is a climate independent water source. It can be an alternative source of drinking water supply, reducing reliance on river as well as subsurface tube well water.

Therefore, the objective of this study was to develop locally constructed solar water desalination units and to guarantee the availability of safe drinking water to the rural population in the coastal area of Bangladesh.

\section{Materials and Methods}

The present investigation was carried out in the Institute of Marine Sciences and Fisheries, University of Chittagong and Khuruskul of Cox's Bazar district (Fig. 1). Desalination techniques are applied to water from a wide variety of sources. In addition to seawater, desalination can be applied to brackish water, river water, wastewater, and even treated water from municipal supplies. However, in this study only the application of seawater was investigated.

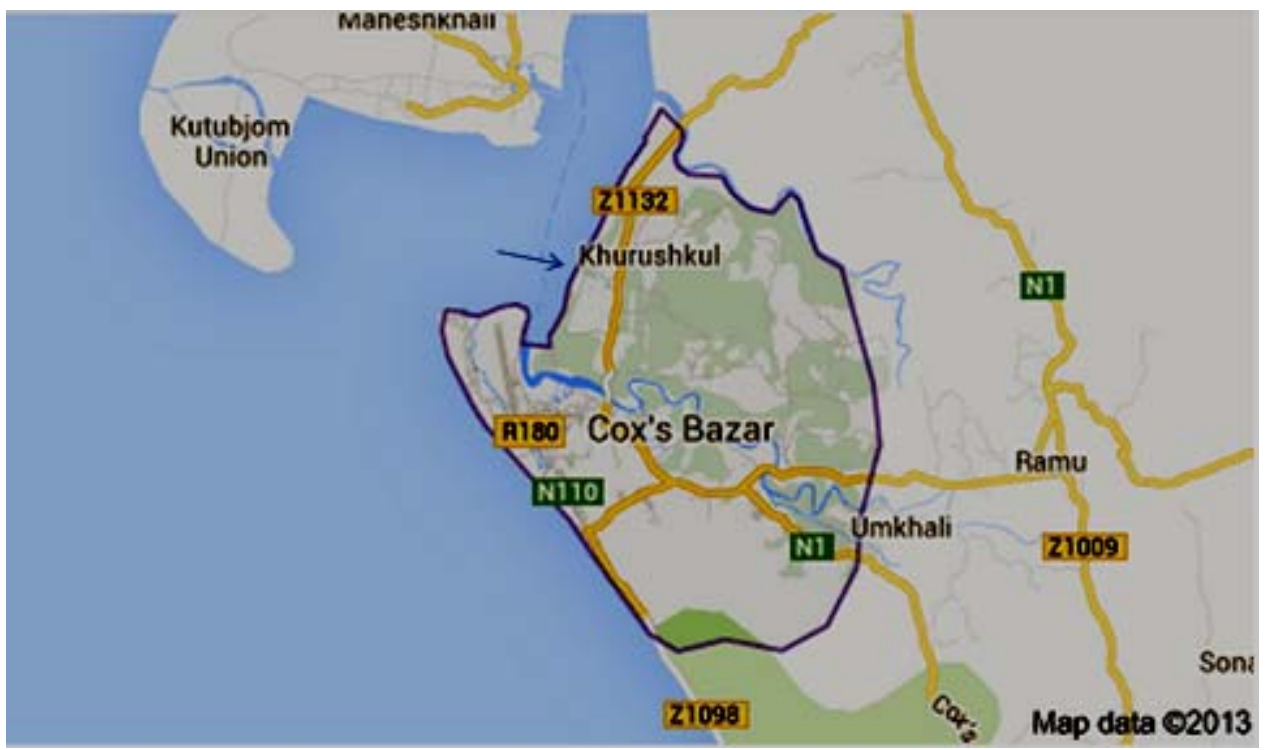

Fig. 1. Study area of the present investigation

Seawater was drawn from the coastal site and was filtered through slow sand filters. Slow sand filter was made through locally available sand, pebble and cobble. Desalinated water is free from pathogens and constitutes a safe source of drinking water in terms of microbes. So the filtered seawater was chlorinated (10 ppm) and dechlorinated before reaching the desalination. 
For the present investigation, 3 experimental seawater desalination plants powered by solar energy were designed, constructed and tested. The principal criteria for selection of materials and development of design of a solar still were the availability of materials, costs involved, efficiency and ease of construction and maintenance.

In phase I of the study, stainless steel was used to construct the solar stills. Because stainless still becomes hot quickly by solar energy in open area and is durable due to iron dust.

In phase II, productivity of the systems was investigated. Two important factors having great effects on the productivity of the solar stills are water depth in the basin and the inclination angle of the glass cover. The main intend of this study was to thoroughly explain the thermal processes occurring in the system, to investigate the effects of water depth and the inclination angle of the glass cover on the productivity of the system and to evaluate the total productivity of the system under the normal climatic condition. The inclination angle of the glass cover and the water area of the basin are shown in Table 1.

Table 1. Area and angle of different Solar stills

\begin{tabular}{|c|c|c|c|c|c|}
\hline Solar Still Number & Length $(\mathrm{m})$ & Width $(\mathrm{m})$ & Height $(\mathrm{cm})$ & $\begin{array}{c}\text { Area of Solar } \\
\text { stills }\left(\mathrm{m}^{2}\right)\end{array}$ & $\begin{array}{c}\text { Angle of glass } \\
\text { cover }\left({ }^{\circ}\right)\end{array}$ \\
\hline Stainless steel 1 & 0.8 & 0.4 & 20 & 0.32 & $45^{\circ}$ \\
\hline Stainless steel 2 & 0.8 & 0.5 & 20 & 0.4 & $35^{\circ}$ \\
\hline Stainless steel 3 & 0.8 & 0.6 & 20 & 0.48 & $35^{\circ}$ \\
\hline
\end{tabular}

Solar still: In this research work, three solar stills were used (Fig. 2). The solar desalination still consists of a reservoir and covered with a glass. The stainless steel sheet was used for the base of solar distillation still and rubber seals were used as insulation. The thermometers were attached to the base to note the temperature of the base and inner space. The glass sheet was used as a cover (tent type) of the solar still's base. The whole system was placed over an angle position in face of the sun. The average cost of the solar still was BDT 2,850.00.

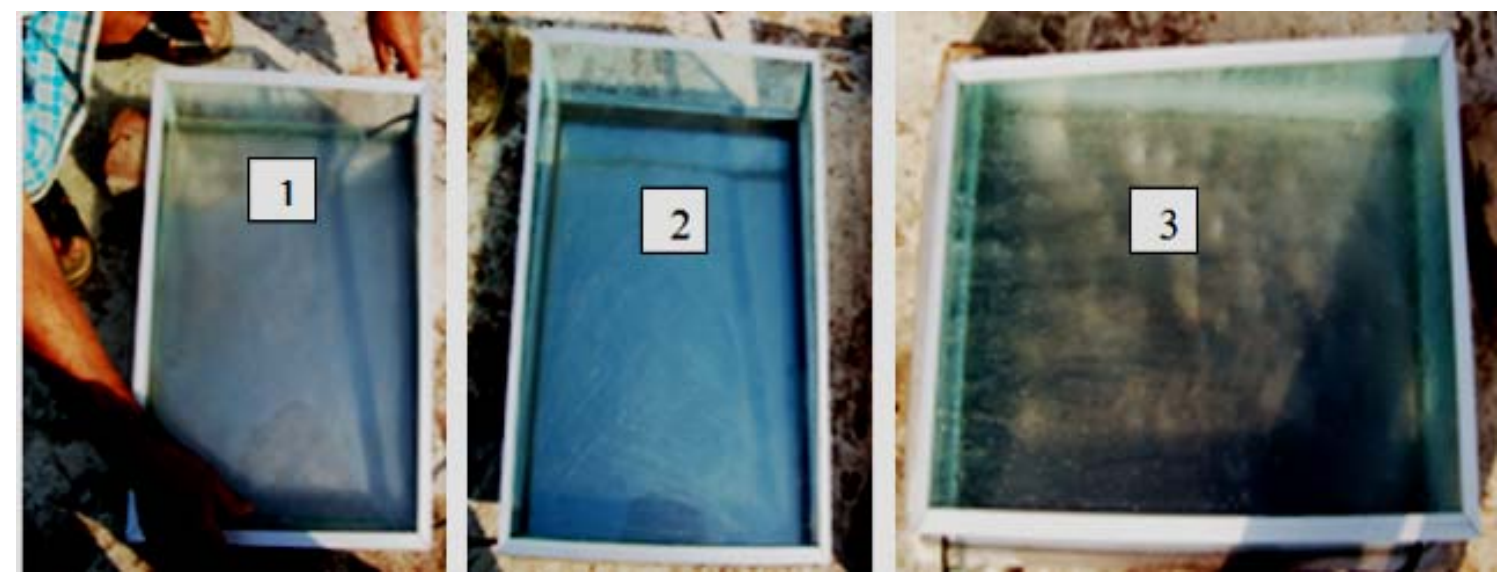

Fig. 2. Three types of solar desalination unit

The working process of solar still was very simple. The filtered seawater was placed inside the stills. These stills were facing the sun with different angle of glass cover (Table 1) and their positions were fixed. Solar radiation passed through transparent glass covers and heat was absorbed by the surface of the stainless stills. These radiations raised the temperature, the water got hot and was evaporated to vapour in the air above the surface. Density of the air reduced due to increase in temperature and caused it to circulate upwards. As a result, the vapour pressure of enclosed air increased and the vapours make contact with the inner surface of the glass cover and relatively cool transparent cover. The liquid condensed, flowed into the base of the cover and finally through the outlets into the container. The distilled water from 3 stills were measured to check the best efficiency of the solar still. The data were recorded for 20 days from 8:00 a.m to 4: 00 p.m 


\section{Results and Discussion}

The present study was concerned with a comparative study of sea water desalination using indigenously prepared solar desalination units. The basic idea of the present study was to compare the efficiency of different solar stills. The performances of these solar stills are shown in Table 2 and Fig. 3. Mineral composition of water before and after desalination is shown in Table 3.

Table 2. Amount of desalinated water from 3 different solar stills (maximum temperature and humidity of the days also observed)

\begin{tabular}{|l|c|c|c|c|c|}
\hline Date & $\begin{array}{c}\text { Solar still- } 1 \\
(\mathrm{ml})\end{array}$ & Solar still -2 $(\mathrm{ml})$ & Solar still -3 $(\mathrm{ml})$ & $\begin{array}{c}\text { Max Temperature } \\
\text { of the Day }\end{array}$ & $\begin{array}{c}\text { Max Humidity } \\
\text { of the Day }\end{array}$ \\
\hline 11.03 .10 & 590 & 450 & 390 & 32 & 52 \\
\hline 12.03 .10 & 505 & 425 & 380 & 32 & 78 \\
\hline 13.03 .10 & 490 & 380 & 350 & 31 & 89 \\
\hline 14.03 .10 & 395 & 320 & 290 & 30 & 94 \\
\hline 15.03 .10 & 450 & 360 & 330 & 30 & 79 \\
\hline 16.03 .10 & 450 & 370 & 335 & 30 & 74 \\
\hline 17.03 .10 & 570 & 460 & 380 & 32 & 78 \\
\hline 18.03 .10 & 685 & 520 & 435 & 33 & 89 \\
\hline 19.03 .10 & 660 & 500 & 410 & 33 & 83 \\
\hline 20.03 .10 & 550 & 440 & 380 & 31 & 84 \\
\hline 21.03 .10 & 490 & 410 & 345 & 32 & 84 \\
\hline 22.03 .10 & 395 & 350 & 300 & 30 & 89 \\
\hline 23.03 .10 & 430 & 360 & 310 & 30 & 79 \\
\hline 24.03 .10 & 440 & 375 & 325 & 30 & 83 \\
\hline 25.03 .10 & 450 & 400 & 330 & 30 & 89 \\
\hline 26.03 .10 & 320 & 290 & 250 & 28 & 89 \\
\hline 27.03 .10 & 440 & 390 & 310 & 30 & \\
\hline 28.03 .10 & 490 & 425 & 360 & 30 & \\
\hline 29.03 .10 & 350 & 320 & 275 & 28 & \\
\hline 30.03 .10 & 400 & 350 & 300 & 28 & \\
\hline Total & 9100 & 7895 & 6785 & & \\
\hline Average & 455 & 394.75 & 339.25 & & \\
\hline & & & & & \\
\hline
\end{tabular}

Table 3. Mineral composition of water before and after desalination

\begin{tabular}{|c|c|c|}
\hline Name of Parameters & Before desalination & After desalination \\
\hline Salinity & $35 \mathrm{ppt}$ & $0.0 \mathrm{ppt}$ \\
\hline $\mathrm{pH}$ & 8.2 & 7.1 \\
\hline Unionized $\mathrm{NH}_{3}$ & $0.5 \mathrm{mg} / \mathrm{l}$ & Absent \\
\hline Chlorine & $2 \mathrm{mg} / \mathrm{l}$ & $0.01 \mathrm{mg} / \mathrm{l}$ \\
\hline Iron & $1 \mathrm{mg} / \mathrm{l}$ & $\mathrm{Absent}$ \\
\hline $\mathrm{NO}_{2}-\mathrm{N}$ & $3.47 \mu \mathrm{g} / \mathrm{l}$ & $0.1 \mu \mathrm{g} / \mathrm{l}$ \\
\hline $\mathrm{DO}$ & $4.8 \mathrm{ml} / \mathrm{l}$ & $3.58 \mathrm{ml} / \mathrm{l}$ \\
\hline
\end{tabular}

\section{Amount of desalinated water $(\mathrm{ml})$}

The desalinated water produced by the stills was collected in the bottle and was measured on daily basis. The maximum desalinated water produced by the still (1) was $685 \mathrm{ml}$, still (2) was $520 \mathrm{ml}$ \& still 3 was $435 \mathrm{ml}$ on (18.03.2010), which was a hot sunny day. During cool and cloudy days the still worked but the distillation rate was reduced.The lowest amount of desalinated water was obtained on a day of lower temperature (26.03.2010) and the amount was $320 \mathrm{ml}$ for still (1), $290 \mathrm{ml}$ for still (2) and $250 \mathrm{ml}$ for still (3). The average amount of water produced by the still (1) was $455 \mathrm{ml}$, still (2) was $394.75 \mathrm{ml}$ and still (3) was $339.25 \mathrm{ml}$. The total amount of water produced by the still (1) was $9100 \mathrm{ml}$, still (2) was $7895 \mathrm{ml}$ and 
still (3) was $6785 \mathrm{ml}$. The temperature and humidity of the investigation period and twenty days observation data of solar still (1), solar still (2) and solar still (3) are shown in Table 2. The amounts of desalinated water by the stills per day are shown in Fig. 2.

Rahman (1993) found that the average yield of a Brick Plant was $1.4 \mathrm{liter} / \mathrm{m}^{2} / \mathrm{day}$. Aybar (2006) studied inclined wick type solar still and concluded that the daily yield of such solar stills is $3.5-5.4 \mathrm{I} / \mathrm{m}^{2} /$ day for summer climatic conditions of Turkey.

Aybar and Assefi (2009) found the best water depth and inclination angle, the accumulative productivity of the desalination system was evaluated under the climatic condition of North Cyprus on a typical day (21st March). The total productivity of the system was $5.3 \mathrm{~kg} / \mathrm{m}^{2} . \mathrm{d}$ while the error of the program was $3.37 \%$ comparing to experimental results.

In the present study the desalinated water obtained were $1.06 \mathrm{l} / \mathrm{m}^{2} /$ day, $0.98 \mathrm{l} / \mathrm{m}^{2} /$ day and $0.95 \mathrm{l} / \mathrm{m}^{2} /$ day from still 1 , still 2 and still 3 respectively.

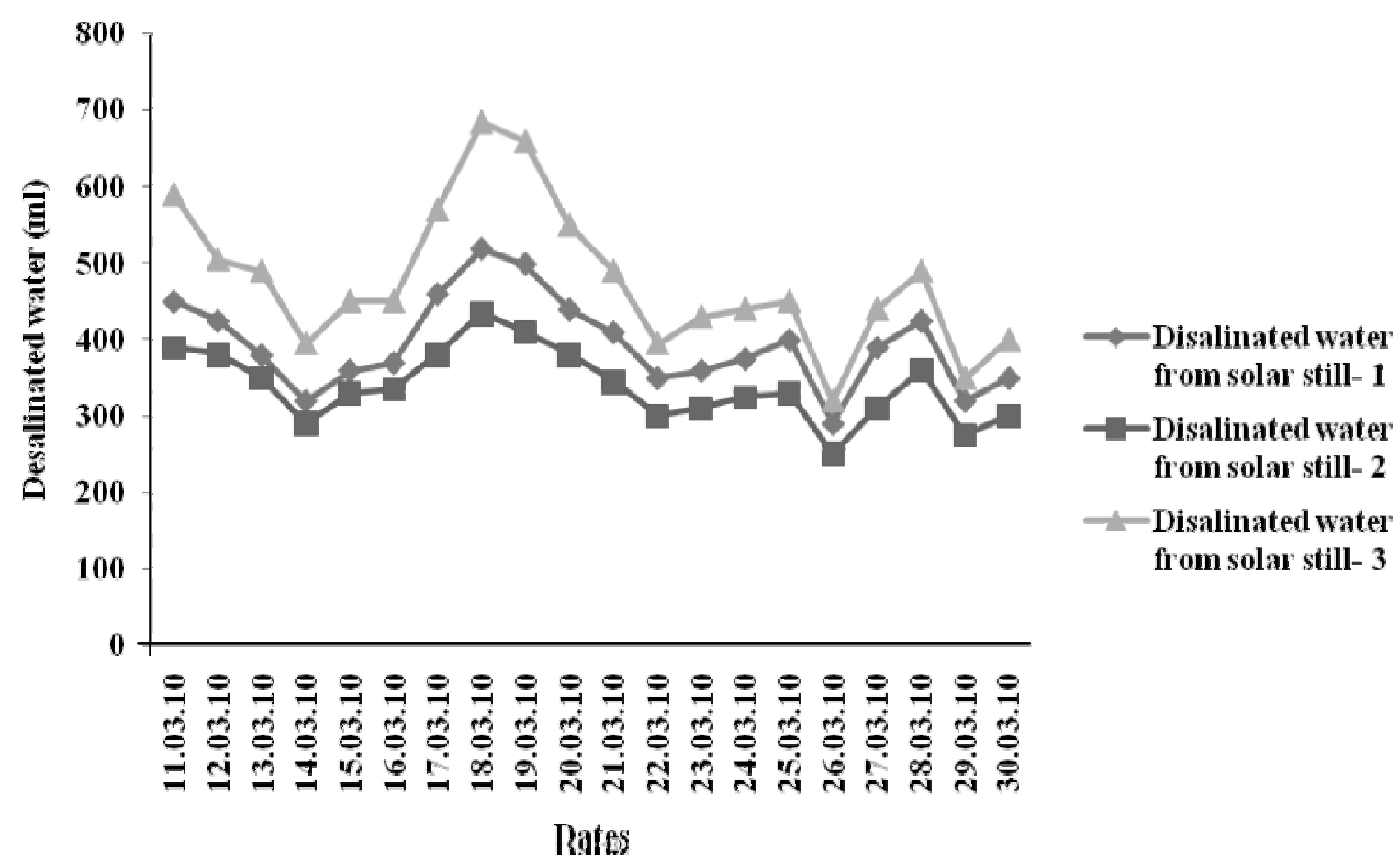

Fig. 3. Amount of desalinated water from 3 different solar stills during the experimental period

A person need 1-2 liters of drinking water a day to live. The minimum requirement for normal life in developing countries (which includes cooking, cleaning and washing clothes) is 20 liters per day. Yet some daily functions can be performed with salt water and a typical requirement for desalinated water is 5 liters per person per day. Therefore $2 \mathrm{~m}^{2}$ of still are needed for each person. The following parameters affected the rate of distillation of water i.e. sunshine hours in a day, temperature, area of the stills and the inclination of the glass cover of the stills.

It can therefore, be recommended that all the solar stills studied are best suited for solar desalination in Bangladesh. If the area of solar stills are increased then output also increases that can fulfill the demand of safe drinking water for poor coastal people of Bangladesh. 
The Government of Bangladesh could consider wider applications of this concept to ascertain the acceptability of this type of technology for supplying safe drinking water to the poor coastal people of Bangladesh

\section{References}

Aybar, H. S. 2006. Mathematical modeling of an inclined solar water distillation system. Desalination. 190, 63-70. DOI:

Aybar, H.Ş., H. Assefi / Desalination and Water Treatment 7 (2009) 35-40.

Bendfeld, J., Broker, Ch., Menne, K., Ortjohann, E., Temme, L., Vob, J., and Carvallo, P.C.M. 1998. "Design of a PV-powered reverse osmosis plant fordesalinationof brackish water," Proceedings of 2nd World Conference and Exhibition on Photovoltaic Solar Energy Conversion, Vienna, Austria, pp. 3075-3077.

Chaudhry, S. 2003. Unit cost of desalination. California Desalination Task Force Issue Paper. Retrieved February 19, 2004 from:

Howe E.D. and Tleimat, B.W. 1977. in: A.A.M. Sayigh, ed., Fundamentals of Water Desalination. Solar Energy Engineering, Academic Press, USA.

http://www.owue.water.ca.gov/recycle/desal/Docs/UnitCostofDesalination.doc.

Joyce A., Loureiro, D. and Collares-Pereira, M. 1993. Internal Report Meeting CYTED, Bariloche, Argentina.

Joyce A., Loureiro, D., Collares Pereira, M. and Moreira, M. 1994. III World Renewable Energy Congress, Reading, UK, pp. 517519.

Malik M.A.S., Tiwari, G.N., Kumar, A. and Soda, M.S. 1982. Solar Distillation, Pergamon Press, Oxford, UK.

Rahman, M.H., Mamtaz, R., Hasan, M.R., Ferdausi, S. and Anisuzzaman, S.M. 1993. Pilot Desalination Project: Bangladesh, Department of Civil Engineering, Bangladesh University of Engineering Technology and Department of Public Health Engineering, Dhaka, Bangladesh. 